\title{
We Chose Microfilm
}

\author{
By FRANCES L. MEALS and WALTER T. JOHNSON
}

TN A survey made of a selected group of 1 junior college libraries in 1958,1 it was discovered that only two of the seventy-nine libraries surveyed were using microfilm to any extent as a means of preserving periodicals. The survey did reveal much interest in periodicals on microfilm by librarians who would like to use microfilm or who were considering using it.

Because of this interest the librarians of the two junior college libraries-Abraham Baldwin and Colby-using microfilm to preserve periodicals felt that their experience with this medium might be of value to others.

Colby Junior College began using microfilm in 1952, and Abraham Baldwin College began in 1956. Each receives twenty-eight titles on microfilm and both purchase the completed films from commercial suppliers rather than attempting to process their own.

Baldwin's back periodical file was in very poor shape in 1955. Few items had been bound professionally and back periodicals were kept in home-made binders, in pamphlet boxes, or just tied up. That a binding program needed to be started was increasingly evident, but since the Baldwin Library was in need of space, there was no room to store the bound items properly. In going through the periodicals selected for possible binding, Baldwin discovered that there were many missing issues which would have to be replaced and thus add to the binding expense.

Colby had a back file of bound periodicals and had moved into a new build-

1 Henrietta Thomae and W. T. Johnston, " A Survey of a Selected Group of Tunior College Libraries" (Mimeographed. 1958). Partially published as "A Glance at Tunior College Libraries," The Junior College Journal, XXIX (1958), 195-202.
Miss Meals is Librarian, Colby Junior College, New London, N. H., and Mr. Johnson is Librarian, Abraham Baldwin College, Tifton, $G a$.

ing in 1950 so that space was not an immediate problem, although the cost of building had made Colby well aware of the need to conserve space. Colby was bothered by the proverbial missing issues at binding time and had also had the sad experience of some articles being clipped from volumes already bound.

Thus the problem of space led both Colby and Baldwin to consider microfilm, and that was the primary reason that both chose to preserve back issues of periodicals on microfilm.

The space-saving possibilities of microfilm in actual practice come as something of a shock even after one has seen the promotion pictures of a bound periodical together with a reel of microfilm of the same volume showing the reduction in size. A nine-drawer microfilm cabinet using 16.2 cubic feet of space will hold 540 reels of microfilm or some 725 periodical volumes, since many titles come two volumes, or twelve months of issues, to the reel. Regular ten-inch double-faced stack shelving would require 123.7 cubic feet or seven and a half times as much space to hold the same number of volumes. On a square footage basis, the difference is not so great as Figure 1 indicates.

The missing and mutilated issues problem was the second reason that both elected to use microfilm. Since the microfilm is supplied in finished form by a commercial firm, one does not have the problem of finding a missing issue to complete a volume. To date, neither has 
had an article clipped from a reel of microfilm, and this seems to be a rather remote possibility since the student does not possess a film reader.

Colby and Baldwin both considered the cost of microfilm versus binding. Microfilm runs about one-fourth cent per page; therefore, the thicker the magazine, the higher the cost. Binding is generally priced according to the height of the magazine with the taller ones costing the most to bind. Table 1 gives a rough comparison of binding and microfilm costs for five magazines of various thicknesses and heights. This comparison indicates that binding is slightly cheaper. In actual practice, Baldwin and Colby have found that the base price of binding and microfilm for the number of titles each receives works out about the same, with microfilm being slightly cheaper. The extras - to borrow an automotive term-are what make the difference. No extras are involved with microfilm except writing and mailing the order, and a one-time standing order can be made. Binding involves several extras: periodicals must be collated and tied; missing and mutilated issues must be secured through purchase or exchange; periodicals must be packed for shipment to the bindery and unpacked on return; and transportation must be paid on smaller shipments. These extras cost in staff time if not in money.

The biggest drawback Baldwin and Colby faced in starting a microfilm program was the initial cost. Microfilm readers run from $\$ 125$ up, with $\$ 350$ being the price of one of the better ones. Humidified storage cabinets start at $\$ 186$, although less adequate storage boxes for a few reels of film can be purchased for a few dollars. One might figure an initial outlay of $\$ 500$ for one reader and one humidified storage cabinet. At Baldwin the space-saving feature was used in presenting the budget request for the extra $\$ 500$ necessary to cover the initial equipment cost.

Baldwin's need for a larger library building is acute. In 1952 part of the

Figure 1

Comparison of floor space required for storage of bound and microfilmed periodicals.
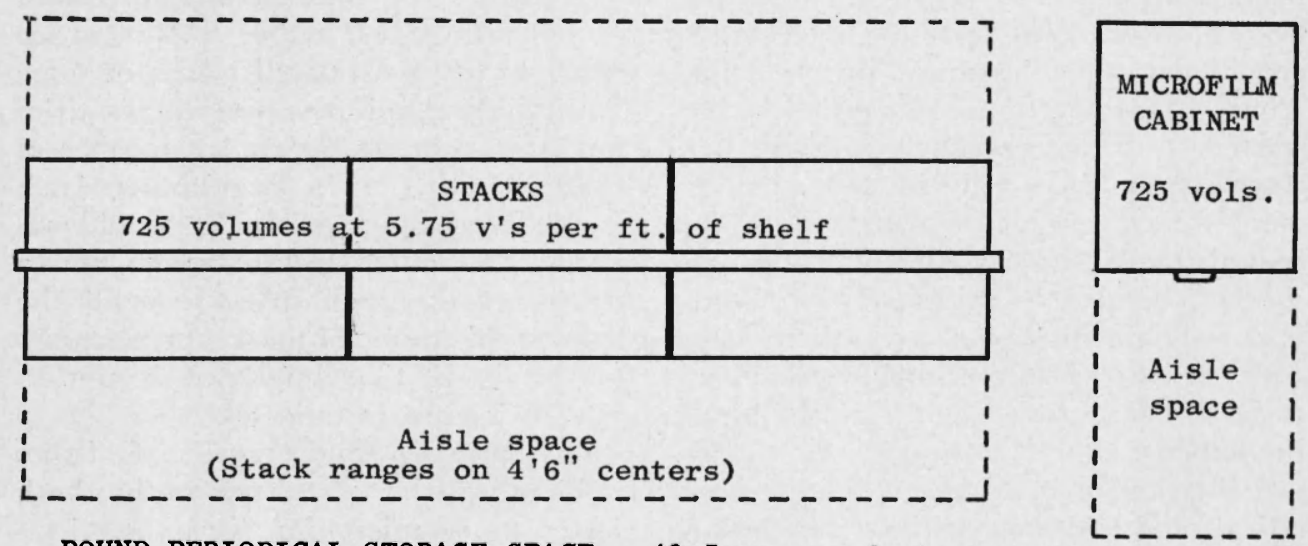

BOUND PERIODICAL STORAGE SPACE: 40.5 square feet MICROFILMED PERIODICAL STORAGE SPACE: $\mathbf{8 . 8 7}$ square feet

Scale: $\underline{1}^{\prime \prime}=1^{\prime}$ 
TABLE 1

Comparison of Binding and Microfilm Costs

\begin{tabular}{|c|c|c|c|c|c|}
\hline PERIODICAL & ISSUED & $\begin{array}{c}12 \text { MONTHS } \\
\text { BOUND AS }\end{array}$ & $\begin{array}{l}12 \text { MONTHS } \\
\text { FILMED AS }\end{array}$ & $\begin{array}{l}\text { BINDING COST } \\
\text { FOR ONE YEAR* }\end{array}$ & $\begin{array}{l}\text { MICROFILM COST } \\
\text { FOR ONE YEAR }\end{array}$ \\
\hline $\begin{array}{l}\text { Reader's Digest } \\
\text { Science Digest } \\
\text { Changing Times } \\
U . S \text {. News and }\end{array}$ & $\begin{array}{l}\text { Monthly } \\
\text { Monthly } \\
\text { Monthly }\end{array}$ & $\begin{array}{l}2 \text { vols. } \\
2 \text { vols. } \\
1 \text { vol. }\end{array}$ & $\begin{array}{l}1 \text { reel } \\
1 \text { reel } \\
1 \text { reel }\end{array}$ & $\begin{array}{r}\$ 6.58 \\
6.58 \\
3.59\end{array}$ & $\begin{array}{r}\$ 7.45 \\
3.50 \\
2.00\end{array}$ \\
\hline $\begin{array}{c}\text { World Report } \\
\text { House and Garden } \\
\text { ToTAL }\end{array}$ & $\begin{array}{l}\text { Weekly } \\
\text { Monthly }\end{array}$ & $\begin{array}{l}4 \text { vols. } \\
2 \text { vols. }\end{array}$ & $\begin{array}{l}2 \text { reels } \\
1 \text { reel }\end{array}$ & $\begin{array}{r}15.36 \\
8.26 \\
\$ 40.37\end{array}$ & $\begin{array}{r}21.08 \\
6.97 \\
\$ 41.00\end{array}$ \\
\hline
\end{tabular}

* Average of prices of three binderies (excluding transportation charges).

$\dagger$ Average of three years 1955 through 1957 (including postage charges).

workroom was given over to periodical storage and in 1954 a small nook was re-partitioned from reading room area to periodical storage area. It was correctly anticipated that microfilm would prevent the necessity of borrowing periodical storage area from another floor area for several years. Of course, the point was made to the librarian that an eventual new building would solve space problems. To answer this argument against the high initial cost of microfilm equipment one can present figures on space costs. Using Figure 1 as a basis, 40.5 square feet of floor space for the storage of bound periodicals will cost at least $\$ 445.50$ if one uses the low building cost of eleven dollars per square foot. To this must be added about $\$ 175$ for nine feet of double-faced teninch library-type shelving. Compared with this, the space for the microfilm storage cabinet will cost $\$ 97.57$ at eleven dollars per square foot, but the space above the fifty-inch high microfilm cabinet can be used for some storage. Adding $\$ 500$ initial equipment outlay to this gives a figure of $\$ 597.57$ for microfilm storage, compared to $\$ 620.50$ for conventional storage. If the cost of the film reader is omitted, the cost of comparable microfilm storage drops to $\$ 283.57$. Figure 2 shows this in diagram form. One might even go so far as to add something for heating, cooling, lighting, and maintaining the larger space required for conventional periodical storage. Consequently, microfilm either means less space needed in a new building or more space for other purposes.

Baldwin and Colby each elected to secure twenty-eight titles on microfilm although each takes many more periodicals than this. The selection was made on the basis of whether or not the publication was indexed in the Readers' Guide and how frequently back issues were called for in the library. There is little similarity between the microfilm lists of the two libraries. Colby also receives the New York Times on microfilm. Since Baldwin had only a small collection of bound periodicals, it has purchased many back reels to try to complete certain holdings from 1950 on.

In selecting equipment, both chose nine drawer humidified film cabinets which are filing-cabinet height. A sixdrawer cabinet, which is table-top height and so permits the film reader to be placed on top, is available, but the ninedrawer cabinet provides more storage space per dollar of cost.

Colby elected to purchase one of the more expensive readers (about $\$ 350$ list). Baldwin chose to buy two cheaper film readers (about $\$ 125$ each) in order to accommodate two users at once. Baldwin feels that in selecting two of the cheaper 


\section{Figure 2}

Comparison of cost for storage of bound and microfilmed periodicals.
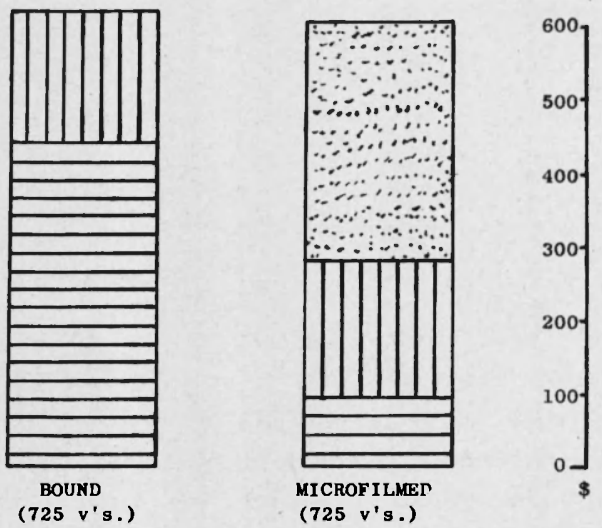

Cost of floor space at $\$ 11$ per square foot.

पD cost of sheiving or cabinet.

Cost of reader (necessary for use, but not for storage of microf $11 \mathrm{~m})$.

readers instead of one more expensive reader it erred because the expensive readers have more refinements which make them easier to use and less likely to scratch film and they also offer slightly greater magnification. The two readers have prevented waiting at times, but Baldwin could easily have gotten by with one reader about 90 per cent of the time, although the second reader is currently receiving much more usage. Colby presently feels the need for a second reader. Both discovered that the reader may be placed anywhere in the library, although the best location is a spot where the room light is about the same brightness as the light projected by the reader and the user does not look up from the reader to face a window.

Colby plans to revamp its serial cataloging and so has not yet listed its microfilm holdings in its public catalog. Baldwin lists its periodical holdings on cards in a catalog drawer marked "Periodi-

cals." To list periodicals held, Baldwin uses a card bearing volume numbers and the notation "Library has those volumes which are dated." On the card in call number position the symbol PB is used to indicate "Periodicals Bound" and PMF is used to indicate "Periodicals on Microfilm." Where both bound and microfilm volumes of a title are held, two cards are used with PB items on one and PMF items on the second. This works well for Baldwin since all bound volumes are older than the microfilmed issues.

Colby follows its open-shelf policy in connection with its microfilm holdings, and a student may go directly to the file, select the film she needs, and use the reader. Because of its building arrangement and the location of its microfilm storage, Baldwin does not apply its open stack policy to microfilm, and the student must ask the librarian for film. At Baldwin, in the event the readers are in use, the student fills a request card and is scheduled to use the reader at another time convenient to him. Both Colby and Baldwin instruct the student in how to use the film reader for the first time and check on his next use to see that he is doing it correctly. Neither attempts to give group instruction in the use of the reader.

The disadvantages of microfilm appear to be few. Perhaps the complaint most often heard is made by those looking for articles on interior decoration, clothing design, travel, etc., for microfilm is black and white and thus color is lost. Not all periodicals are available on microfilm from commercial suppliers, but 78 per cent of the titles indexed in Readers' Guide to Periodical Literature can be obtained on microfilm, and Baldwin and Colby have found this sufficient for their needs.

Microfilm is usually supplied anywhere from several weeks to several months after the periodical year is com-

(Continued on page 228)

COLLEGE ANDRESEARCH LIBRARIES 
have seen the subscription totals of all of the journals increase sharply; all but one are well over the five-hundred mark. The Soviet Physics-JETP subscription list now approximates one-thousand. Subscription prices now range from approximately one to two and one-half cents per page, nonprofit academic libraries taking the lower rate.

When related to the benefits of the program, the cover-to-cover translation journals are viewed as a relatively inexpensive means of acquiring the results of much valuable research. In absolute terms, of course, the program is not without its cost. But until such time as a knowledge of Russian is much more widespread or until machine translation is perfected, the most effective method of communicating Soviet developments to the West would appear to be by the delivery to the scientist, five to seven months after publication of the originals, the authoritative, complete translations. The rising use of the latter points to a firm acceptance of the present translation program by the physicist and the research librarian who serves him.

\section{We Chose Microfilm}

(Continued from page 226)

plete. Since the paper issues are not sent away for processing as in binding, the library always has a complete file available for use. Both the Colby and Baldwin libraries dispose of the magazines which have been replaced by microfilm.

In comparing notes, Colby and Baldwin agree on the advantages and disadvantages of microfilm except for one item. Colby feels that films are easier to use since one does not have to handle weighty volumes of periodicals. Baldwin considers bound volumes slightly easier to use since the librarian does not have to give instructions in film reader operation and since a page is easier to find than a frame of microfilm. To see the frame-finding problem, one must realize that microfilm is stored on hundred-foot reels which accommodate twelve issues of monthly magazines, and in using microfilm one always starts at the front of the reel. For example, if the November issue is wanted, one must reel through January, February, March, etc., to reach November. The experienced microfilm reader soon learns to "watch for the cover," which is a single page frame causing a light flick and enabling one to count months while winding film at a rapid rate, and so find the right month with a minimum of time; but frequently the beginning microfilm user complains that it takes him several minutes to find the right frame. However, Baldwin considers this a minor complaint.

One unexpected advantage that came to Baldwin and Colby from their microfilm programs is that both are able to provide microfilm readers for faculty and non-college personnel borrowing or buying microfilm materials in connection with research or graduate study. Colby feels that this has made many offcampus people friends of its library.

The librarians of Baldwin and Colby are pleased with the space and moneysaving features of microfilm and consider it an excellent solution to many problems involved in keeping and in using back issues of periodicals, especially in the small library which is limited in space, staff, and funds. Most students are intrigued by microfilm and delight in finding opportunities to use it. 